FREP

1,1

4

Received 16 March 2021

Revised 5 May 2021

Accepted 21 May 2021

\section{Understanding political influences on Southeast Asia's development experience}

\author{
Dwight Perkins \\ Department of Economics, Harvard University, Cambridge, Massachusetts, USA
}

\begin{abstract}
Purpose - The per capita GDP of the countries of Southeast Asia (SEA) varies from less than $\$ 5,000$ to over $\$ 97,000$. This paper aims to analyze the political factors behind such variation, such as wars, extreme politics, political instability, and kleptocratic governments and leaders, and how they affect the development experience within the region.

Design/methodology/approach - This paper uses the comparative political economy analysis approach to make a comparison among SEA countries using knowledge from well-known political-economic history and development data from World Development Indicators provided by World Bank.

Findings - A long period of political stability creates a favorable environment for investment that, in return, stimulates sustained economic growth in SEA. The countries have all grown rapidly, but their experience of development varies. The four countries that avoided political extremes (Singapore, Malaysia, Thailand and Brunei) have the highest per capita incomes today. Those that have had long periods of war and political instability, but which have also had substantial periods of stability (Indonesia, Vietnam and the Philippines), come next. Cambodia and Laos have suffered long periods of war and are the least developed. Myanmar's military rulers, through civil wars and kleptocratic mismanagement of the economy, have prevented growth much of the time.

Originality/value - Most studies of Southeast Asian growth have analyzed the experience of single countries and missed the central role played by extreme politics, including wars, to explain why some countries have much higher per capita incomes than others. This paper is expected to fill this gap.
\end{abstract}

Keywords Southeast Asia, Economic growth, Extreme politics

Paper type Research paper

\section{Introduction}

The nations of Southeast Asia contain 661 million people (in 2019), or 8.6\% of the world's population (World Bank, 2021). Indonesia alone is the world's fourth-largest country in terms of population, but outside the region, little attention has been paid to Southeast Asia's experience of economic development. This is to be regretted because the region shares many of the historical characteristics of other parts of the developing world in ways that the much better-known experience of Northeast Asia (Japan, Korea, Taiwan, and Taiwan and Hong Kong in Greater China) does not. Except for Thailand, all the countries of Southeast Asia were colonies of European powers, all were richer in natural resources than the resourcepoor nations of Northeast Asia, and, except for Vietnam, none had long traditions of welleducated elites. In addition, many Southeast Asian nations have diverse populations that

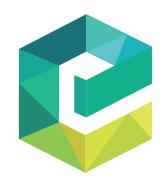

(C) Dwight Perkins. Published in Fulbright Review of Economics and Policy. Published by Emerald Publishing Limited. This article is published under the Creative Commons Attribution (CC BY 4.0) license. Anyone may reproduce, distribute, translate and create derivative works of this article (for both commercial and non-commercial purposes), subject to full attribution to the original publication and authors. The full terms of this license may be seen at http://creativecommons.org/licences/by/4.0/ legalcode

The author thanks David Dapice and Malcolm McPherson for reading and suggesting changes and additions that have improved this paper. and Policy

Vol. 1 No. 1, 2021

pp. $4-20$

Emerald Publishing Limited

e-ISSN: 2635-0181

p-ISSN: 2635-0173

DOI 10.1108/FREP-03-2021-0021
Fulbright Review of Economics 
speak different languages. Japanese and Koreans, in contrast, mostly speak one respective language; even China, with its enormous population, has a common written language used by all who can read.

The first decades after the Second World War were painful for much of Southeast Asia. In Indonesia, the Dutch first fought to hold on to their colony in the region, and when they withdrew, independent Indonesia was led by a charismatic figure, President Sukarno, who was more interested in playing a prominent role on the international stage that included threatening war with Malaya when it incorporated parts of northern Borneo to form Malaysia. At home, Sukarno tried to lead by maintaining a balance between a vigorous communist movement and the national army, which ended in the bloodbath of 1965. The French attempted to reassert control over Indochina. Although this ended in 1954, it was followed by a civil war in Vietnam that also engulfed Laos and Cambodia, got caught up in the Cold War, and lasted for two decades. Although the British reestablished control over Malaya from the Japanese in 1945, they then fought a war (the "Emergency") that involved mainly parts of the Chinese population of the Malay Peninsula, delaying Malayan independence until 1957. Independence was followed several years later by the incorporation of Singapore into Malaysia, although it was then forced to withdraw and become a separate independent country. Burma (Myanmar) gained independence from Britain peacefully in 1948 but soon descended into civil wars involving its large minority populations. These have still not been fully resolved at the time of publication (2021). The Philippines also gained independence peacefully in 1946, but it soon fought a major communist insurgency and then descended into two decades of misrule by Ferdinand Marcos that left the economy in shambles.

I mention this well-known history simply to make the point that there was no economic development to understand while these wars, mismanagement and struggles for independence were underway. Using a comparative political economy approach, this paper will focus first on the economic impact of these political events and then turn to what happened after the wars and political struggles ended. As analysis will make clear later in this paper, independence in many Southeast Asian countries did not automatically create a supportive political environment for economic development.

Around the time that they achieved independence, most of the nations of Southeast Asia were by no means among the poorest countries in the world, even if one excludes Brunei, with its tiny population and great oil wealth, and Singapore, the dominant port city in the region (Table 1). Indeed, by 1960, most of the other countries of Southeast Asia were significantly richer per capita than India or China. Myanmar was the notable exception, however, if the data are roughly accurate. The data for Vietnam, Cambodia and Laos are for the 1980s, but it is likely that if an estimate for 1960 were available, per capita incomes in the three countries would have been similar or even a bit higher than later, after long years of war.

In addition, all the countries of Southeast Asia apart from Myanmar had higher per capita incomes than the Republic of Korea in 1960, just before it began its accelerated growth spurt. At that time, Malaya and the Philippines had per capita GDPs more than double that of Korea (Shah, 2017). By 2019, in contrast, Korea's per capita GDP was higher than the highest Southeast Asian economy, if one excludes Brunei and Singapore. Malaysia in 2019 remained by far the richest country after Singapore, Thailand had risen to third place and the Philippines had fallen to fourth place, only slightly ahead of Vietnam and Laos. Myanmar had risen above Indonesia and Cambodia, if the figures can be believed since its economic data are suspect. The remainder of this paper will attempt to explain why the pattern just described occurred. 


\begin{tabular}{llrr} 
FREP & Countries & 1960 & 2019 \\
\cline { 2 - 4 } 1,1 & Brunei & 87,657 & 62,100 \\
& Singapore & 5,796 & 97,341 \\
& Malaysia & 3,076 & 28,364 \\
& Thailand & 1,621 & 18,460 \\
& Philippines & 2,935 & 8,908 \\
$\mathbf{6}$ & Indonesia & 1,831 & 11,812 \\
& Vietnam** & 1,460 & 8,041 \\
Laos** & 1,799 & 7,826 \\
& Cambodia** & 1,764 & 4,389 \\
& Myanmar & 489 & 5,142 \\
& Rep Korea & 1,390 & 42,879 \\
& China** & 598 & 16,117 \\
& India & 1,028 & 6,700
\end{tabular}

Note(s): *Purchasing power parity estimates using the PPP methodology are not available before 1990 . These estimates for 1960 and other earlier years were derived in effect by assuming that the GDP per capita in 2017 PPP international prices was the same as the per capita GDP growth rate in constant 2010 US dollars. The Table 1. Myanmar estimate for 1960 is unreliable

Per capita GDP (PPP **Vietnam and Laos are for 1983-1984, Cambodia is for 1993 and China for 1978

2017 international \$)* Source(s): World Bank (2021)

\section{Economic growth is incompatible with many kinds of politics}

To explain the patterns of economic growth in Southeast Asia, why some countries did better than others, and why some did well for a time and then performed poorly, one needs to begin with the politics. Politics have typically been left out of regression equations used to explain growth, although there are notable exceptions (Alesina et al., 1996). In contrast, a recent influential study argued that sustained economic growth is only likely if a country moves toward the active participation of its population in the political process - or, in slightly oversimplified terms, moves from authoritarian to more democratic forms of governance (Robinson and Acemoglu, 2012). Neither of these approaches, however, explain by themselves why some Southeast Asian economies did better than others. Adding a political variable to the growth equations does not help much because there are many different kinds of politically motivated actions that can interfere with growth. The kinds of politics we are interested in the first part of this paper are what I label as extreme politics that lead either to great instability (including war) or involve predatory or extreme ideologically driven governments. Both kinds make sustained economic growth difficult, if not impossible. In the latter part of this paper, we will explore some of the other reasons for the differences in performance of Southeast Asia economies at times when extreme political actions were not involved.

To identify how extreme politics influenced economic growth, our approach is to briefly review the political histories of each of the countries in the region. The role of politics in this analysis focuses on the motives, beliefs and ideologies of individual leaders and ruling elites and how they responded to different challenges - particularly, but not exclusively, challenges from those they were attempting to govern. As we go through the histories of the various Southeast Asian countries, it is useful to keep in mind the comparative experience of Northeast Asia, where from at least 1960 onwards, with the notable exception of China, none of these economies (Japan, Republic of Korea, Taiwan and Hong Kong) experienced sustained political instability that significantly interfered with economic growth. In China's case, the same can be said only for the period beginning in 1978 . 


\section{Three countries with sustained economic growth}

We will start with the two highest income countries in the region (excluding Brunei), Singapore and Malaysia, and then move on to Thailand, the third. Malaysia and particularly Singapore were the richest countries in Southeast Asia at the time of their independence largely because they had experienced a steady expansion in the production and export of rubber and tin during the colonial period. The colonial government had built what for the time was good infrastructure, with excellent port facilities in Singapore, paved roads in Malaya, electric power and even potable water supplies, at least in the cities (Shah, 2017). The years of the Emergency (1945-1957) limited investment, but Malaya still benefited from the Korean War boom in rubber and tin prices. When the Emergency ended, Malaya (and later Malaysia) enjoyed uninterrupted political stability from that point onwards, with the notable exception of the 1969 "riots". However, this event, which led to the New Economic Policy (NEP), only disrupted the economy for a few months. The NEP bought with it decades of political peace as the United Malay National Organization (UMNO), along with its smaller allied parties, dominated the government for the next nearly five decades. Reasonably honest elections were held and leaders changed, although Mahathir Mohamed was Prime Minister from 1981 to 2003. The economy remained open with liberal trade policies and welcomed the foreign direct investment (FDI). There were, however, biases in policies that favored Malays over other ethnic groups; there were also policy mistakes and there was increasing corruption, particularly among the political elite. There was nothing, however, that seriously interrupted a stable environment for FDI that accounted for most exports and much of GDP growth.

Singapore, as noted, inherited the infrastructure and free trade policies of what had for a long time been the major port of Southeast Asia. Unlike Malaysia, its population was predominantly Chinese, and the communist insurgency had strong support among many of these Chinese Singaporeans. After the insurgency had been defeated, there remained a contest between the more radical factions of the emerging political groups and a group that was more "conservative", albeit still socialist. That contest was in turn partly related to the division between those who had been in Singapore for generations and spoke English and those who primarily spoke one of the Chinese dialects (mainly Cantonese, Hakka and Hokien). When this author first visited Singapore in 1962, it was not at all clear which of these factions would win out. Labor strikes were common. To simplify a more complex process, the basic fight for control mainly occurred within the People's Action Party (PAP), with the more "conservative" faction led by Lee Kuan Yew winning out in part with the help of the British colonial government. The British Crown Colony ended in 1963 when Singapore became a province of Malaya, but it was then expelled from Malaya and became an independent country in 1965. During this period of political turmoil from 1960 to 1965, Singapore's GDP still grew at a respectable $6 \%$ a year. With full independence, however, it jumped to an annual rate of $12.5 \%$ over the next eight years (World Bank, 2021).

From 1965 onwards, Singapore has experienced uninterrupted rule by a PAP dominated first by Lee Kuan Yew and then his handpicked successor and most recently his son. The government is democratic in the sense that it holds elections in which the votes are honestly counted and there is opposition, but there are many constraints on the opposition that make the system inherently more authoritarian than democratic. From the viewpoint of economic growth, the government has systematically supported pro-economic growth policies together with a substantial social welfare program. State-owned enterprises have also been supported, although they have been expected to compete in much the same way as private companies. For example, Singapore Airlines, one of the most successful carriers in the world, is a stateowned enterprise, but it still competes on all routes with numerous other airlines since Singapore has no domestic air transport. Open-economy free trade policies have never been challenged, although there is some government-targeted support for particular sectors. It is

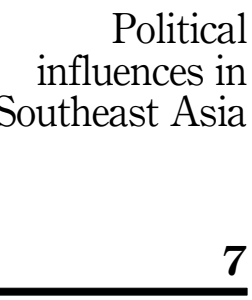


FREP

1,1

8 doubtful that there is any country in the world that has maintained such a consistent a set of growth-oriented and efficiently implemented politics over such a long period.

Thailand is the one other country of Southeast Asia that has experienced long periods of substantial economic growth. It is also the only country in the region that was never a colony of a European or any other power. Thailand's absolute monarchy became a constitutional monarchy in 1932, and in the immediate aftermath of the Second World War, the government was run by a military dictatorship until 1973. After that, it became a kind of parliamentary democracy that saw changing parties and prime ministers in part through elections but also occasionally through military coups. Thailand has had many military coups, but most of them have involved little violence or economic disruption. This system has produced a reasonably stable environment for investment and economic growth. There was no years of negative growth between 1960 and 1996 when GDP growth and growth per capita averaged 7.6 and $5.3 \%$, respectively - a high rate by any measure. The Asian financial crisis of 19971998 began in Thailand and resulted in a $12 \%$ fall in per capita GDP. The economy took threeplus years to recover to the per capita GDP level of 1996. The years from 1997 onwards were dominated by the populist political parties of Thaksin Shinawatra and his sister and the army coups that removed them from office in 2006 and 2014, respectively. GDP and GDP per capita growth fell sharply from 7.6 to $5.3 \%$, respectively, from 1961 through 1996 to 3.0 and $2.6 \%$ during the populist and coup years of 1997 through 2013. Growth continued at that slower pace through 2019 before falling 6.5\% in 2020 due to the coronavirus (World Bank, 2021). The political instability arising from a political divide between the interests of the ruling elites and residents of Bangkok, on the one hand, and Thais in most of the rest of the country who supported the populist parties, on the other, probably accounts for most of this slowdown. That said, there has been no time in Thailand from the 1950s onwards when the country experienced periods of many years with stagnant or negative growth. Political instability and corruption have been a problem for the economy but not to the degree that has characterized the following Southeast Asian countries.

\section{Six countries where war and politics led to long periods of stagnation}

The Philippines, the next richest country in the region after Malaysia and Singapore (excluding Brunei) at the time of its independence, is the first example in this paper of how extreme politics can seriously interrupt economic development. In the immediate postindependence years, democratic elections produced a series of presidencies that dealt with recovery from Japanese occupation during the Second World War, but these were soon facing a major Communist-led insurgency. Despite that, the country did experience some economic growth, and Ferdinand Marcos, when he was elected president in 1965, pursued a vigorous debt-financed infrastructure program that helped him to be elected for a second term.

In this second term, however, there was inflation and social unrest that led Marcos to declare martial law in 1972. From that point onward, the economic situation began to deteriorate as Marcos pursued activities designed to generate funds for himself and his associates. The degree to which banks and other institutions were hollowed out was covered up with false statistics, but per capita GDP growth continued through 1980. If the estimates are reliable, growth continued at a respectable $2.5 \%$ a year. From 1981 onward, however, inflation was rampant, and the economy declined rapidly, falling by almost $18 \%$ per capita through 1986 (World Bank, 2021). The People Power Revolution drove him from office in 1986, so he fled the country, and Corazon Aquino was elected as the president. The Aquino years were mostly occupied with recovering from the debt and deterioration of the Marcos years but were also plagued by military coup attempts that undermined investor confidence. GDP growth was negative in both 1991 and 1992. From that point onward, however, under several presidencies and more than a few crises, GDP grew at an average rate of $5 \%$ per year 
and per capita GDP grew at an annual rate of $2.9 \%$, more than doubling per capita income (World Bank, 2021). Put differently, the Marcos kleptocracy and its unstable political aftermath cost the Philippines roughly 20 years of per capita growth - per capita GDP in 1977 was not surpassed until 1997. In other words, total GDP during these two decades just kept up with the comparatively high population growth rate of $2.05 \%$ per year over the same period.

Economic growth in Indonesia in the late 1990s had some features in common with the Marcos years in the Philippines, but the impact of extreme kleptocratic politics on the Indonesian economy was short-lived by comparison. The major political drag on the economy occurred in the first two decades after Indonesia declared independence from the Dutch in 1945. That led the Dutch to try to hold on militarily until they were forced to recognize Indonesian independence in late 1949. During the presidency of Sukarno, however, the president and the government were primarily occupied with international political affairs that included driving the Dutch and most other foreign investors out of Indonesia. They also declared war on Malaya in an attempt to prevent the states of northern Borneo (Sabah and Sarawak) from being incorporated into the new Malaysia. They also declared war again with the Dutch over the western half of New Guinea. The period ended with the bloodbath of 1965, which was connected with the long contest for power between the Indonesian communists and the army. Per capita GDP in the early 1960s was probably no higher than it was in the 1950s or the 1920s. The first few years of military rule mainly involved recovery from the chaos of 1965 , and there was a brief debt crisis in the 1970s when Indonesia borrowed heavily on the assumption that oil prices would continue to climb and then invested these funds poorly.

The only subsequent political action that had a major negative impact on GDP growth was the rising corruption of the Suharto family and associates in the 1990s after President Suharto decided in 1992 for another term in office. That rising corruption and increasing public and private debt, much of it borrowed in foreign currencies, caught up the country in the Asian financial crisis. That in turn engulfed Indonesia in a political crisis with the fall of Suharto, transition to democracy and early years of democratic rule that mainly involved recovery from the decline in the economy. Per capita GDP did not recover to the 1997 level until 2004. In effect, seven years of growth were lost (but democracy was gained) to go with the 20-plus years lost in the immediate post-independence decades. In contrast, during the politically stable years of 1968-1996, GDP and GDP per capita grew at 6.4 and $4.4 \%$, respectively. From 2005 to 2019, before the COVID-19 pandemic, GDP and GDP per capita grew at a slower but still substantial rate of 5.5 and 4.1\%, respectively (World Bank, 2021). These periods of substantial growth will be discussed later in this paper.

The three countries of Indochina gained full independence from France in 1953 and 1954Cambodia and Laos peacefully, Vietnam only after a protracted war that left the country split into two. That, in turn, led to a war that eventually led to the unification of the two parts of Vietnam in 1975. However, the leadership of the unified Vietnam then chose to attempt to impose a complete Soviet-style centrally planned command economy including collectivized agriculture on the south (the system already existed in the north). This effort failed, and in the process of failing, it in effect made sustained economic growth impossible. The political leadership of Vietnam changed in 1986, but sustained economic growth did not begin until a dramatic change in the economic system began to be implemented in 1989. Laos and Cambodia were unable to keep from being dragged into the war in Vietnam. Cambodia then experienced the genocide of the Khmer Rouge that was ended by an invasion by Vietnam. Sustained economic growth in Cambodia did not begin until the country abandoned a Soviettype system and replaced it with a market system in 1995. Growth in Laos may have started earlier. Overall, the countries of Indochina attained sustained GDP growth only from the end of the 1980s [1]. For the 30 years through 2019, and before the pandemic, the political systems of all three countries have been stable and grown rapidly, although for very different reasons that will be discussed later. 
FREP

1,1

The Myanmar economic experience belongs in a category of its own. To begin with, economic data produced by the military governments that ruled Myanmar from 1962 to 2011 are highly suspect. This is particularly the case for data covering the 1992-2011 period that showed per capita GDP rising at nearly 9\% a year (World Bank, 2021). There was hardly any manufacturing in Myanmar during that period beyond rice mills and a few textile and garment producers. Officially, exports were less than one percent of GDP because of the international embargo on trade with the country. Exports of items such as precious stones (rubies, jade, etc.) were large but most were smuggled out of the country and did not appear in the official statistics.

The history of Burma/Myanmar also makes it clear that there was little if any economic growth after the time of independence from British colonial rule in 1948. The civilian government of $\mathrm{U} \mathrm{Nu}$ introduced Burmese socialism, which had the immediate effect of ending economic growth. In 1962, the military took over the government in a coup and military rule continued uninterrupted until the election of 2015, although preparations for a return to partial civilian rule began in 2011. The military spent most of their time in power fighting the various minority groups (Shan, Kachin, etc.) that made up nearly one-third of the country's population. The military and civilians close to it were unusually corrupt. In 2012, Transparency International ranked Myanmar's level of corruption at No. 172 out of 176 countries surveyed (Transparency international, 2012). After 2011, the government did manage to arrange truces in fighting with most of the minority groups except the Kachin in the north of the country. Growth also began as the embargo was lifted and FDI began to pour in. The World Bank's estimates of GDP growth and GDP per capita growth in 2012-2019 of 6.6 and $5.8 \%$, respectively, are plausible. If there was any growth in per capita GDP before 2012, it was likely siphoned off by the military, cronies and smugglers. Per capita income growth for over $80 \%$ of the population was effectively nonexistent.

To summarize this discussion of the impact of extreme predatory politics and war on economic growth in Southeast Asia, six of the nine countries (the ASEAN countries minus Brunei) experienced long periods of no or negative growth due to predatory politics and war. Only three countries - Singapore, Malaysia and Thailand - avoided long sustained interruptions of that kind. The estimates in Table 2 give a quantitative picture of the impact of these sustained interruptions in growth on the overall increase in per capita GDP in the nine major countries of Southeast Asia. Malaysia had the slowest GDP per capita growth rate of the three countries that avoided long-stagnant periods. Nevertheless, Malaysia still achieved more than a ninefold increase in per capita. Thailand grew over elevenfold, but it had started with only half the per capita income of Malaysia and so had only caught up to $65 \%$ of Malaysia's per capita GDP. The Philippines had slower growth than most other countries during the 20th century and also had two decades of no growth. As a result, Philippine GDP per capita almost equal to that of Malaysia in 1960 - fell to less than one-third of Malaysian GDP by 2019. The Indochina countries grew more rapidly than the others, but only after the end of the long wars of independence and reunification, and so they were still well behind in terms of per capita income. Myanmar is an extreme case. Despite what the official figures indicate, there was little increase after independence in the per capita income of the great majority of the population. If there was a significant increase in GDP, it was probably almost entirely absorbed by the army and its close civilian associates. The GDP growth illustrates clearly the impact of stagnant years on the growth of the countries of Southeast Asia (Table 2).

\section{Differences in economic performance not due to war or extreme predatory governments}

While war and the extreme predatory behavior of some Southeast Asian governments explain much of the observed differences in performance of these nine countries, they clearly do not explain all the differences. Singapore grew faster for a longer period than any of the 


\begin{tabular}{|c|c|c|c|c|c|}
\hline & $\begin{array}{c}\text { Stagnant } \\
\text { Years }\end{array}$ & $\begin{array}{l}\text { Growth } \\
\text { Years }\end{array}$ & $\begin{array}{c}\text { GDP p.c } \\
\text { Growth Years \% } \\
\text { per year }\end{array}$ & $\begin{array}{c}\text { Index GDP per capita } \\
1960=100\end{array}$ & $\begin{array}{r}\text { Political } \\
\text { influences in } \\
\text { Southeast Asia }\end{array}$ \\
\hline Singapore & None & $1961-2019$ & 4.9 & 1680 & \\
\hline Malaysia & None & 1961-2019 & 3.8 & 922 & \\
\hline Thailand & None & $1961-2019$ & 4.2 & 1139 & \\
\hline Indonesia & 1961-1967 & 1968-2019 & 3.6 & 645 & 11 \\
\hline \multirow[t]{2}{*}{ Philippines } & $1981-2001$ & $1960-1980$ & 2.4 & & \\
\hline & & 2002-2019 & 3.9 & 303 & \\
\hline Vietnam & 1961-1988 & 1989-2019 & 5.5 & 519 & \\
\hline Laos & 1961-1988 & 1989-2019 & 5 & 458 & \\
\hline Cambodia & 1961-1994 & 1995-2019 & 5.6 & 395 & \\
\hline Myanmar & $1961-2011$ & $2012-2019$ & 5.8 & 157 & \\
\hline
\end{tabular}

Note(s): Stagnant years are defined as years with little or no growth over a sustained period of many years. The term does not include a recession of one or two years in length. The GDP per capita growth rate is only for the years during which there was sustained growth, not growth over the entire period since 1960

The Index for growth in GDP per capita for most countries is obtained by dividing GDP per capita in 2019 with that in 1960 . However, WDI online for Vietnam and Laos only reports GDP per capita in constant local currency prices beginning in 1984, and growth in these countries did not begin until several years later, so the index is 2019 per capita GDP over 1988 per capita GDP. For Cambodia, it is GDP per capita in 2019 over 1994

WDI online reports GDP per capita for Myanmar going back to 1960, but the data for 1991 - 2011 indicating a per capita GDP growth rate of $8.8 \%$ per year is completely implausible. There is ample reason to believe that the Myanmar military falsified the GDP estimates for most of the years that they were in power until they began to make way for some degree of civilian rule in 2011. In further support of this view, David Dapice, in a personal communication, stated that in a meeting with the Minister/General in charge of statistics in the very early 2000 s, he queried how Myanmar's GDP growth was so high when his calculations of growth in major products were so much lower. The General replied that that was because Senior General Than Shwe (then the dictator of the country) had stated what the GDP growth should be, and the General made it happen. For Myanmar, the growth rate and index reflect GDP per capita growth rate only from 2010 to 2019

Source(s): WDI, World Bank (2021)

Table 2.

Stagnant years impact on growth

others. If one were to focus only on when Singapore was still at a middle-income level and experiencing catch-up growth (between 1960 and 1990), per capita GDP grew at 6.6 per year. Only the governments of Vietnam, Cambodia and Laos came anywhere close to that Singapore catch-up growth rate (Table 2). These three Indochina economies, however, started from a low per capita income that made possible a longer period and possibly a higher rate of catch-up growth feasible. All countries that have experienced rapid catch-up growth begin to experience a slowing of the GDP growth rate long before they fully catch up to the per capita incomes of the high-income countries. Singapore experienced such a slowdown in per capita GDP growth in the late 1980s. Malaysia, in the late 1990s, also reached a level of per capita GDP at which many other countries stop growing at high catchup growth rates [2]. None of the other countries in the region (except for Brunei) have yet reached per capita GDP, whereby a slowdown of this kind might be expected [3]. Vietnam, because it started later and from a low per capita income, may experience high catch-up growth for another two decades.

A systematic explanation of why several Southeast Asian economies have grown somewhat faster than others during periods when major political disruptions were absent is well beyond what can be accomplished in this paper. Instead, we will give a broad-brush picture of some of the reasons why most Southeast Asian economies have grown rapidly in comparison to many developing countries but fallen short of the sustained very high growth rates of economies such as South Korea and Taiwan (and Singapore). We will start with a general picture of what most of the growth accounting exercises tell us. 
FREP 1,1

Growth accounting exercises are estimated in a variety of different ways, making comparisons difficult. The growth that is explained can be GDP growth in constant prices, per capita or per worker. The data sets used to make these estimates can also vary, particularly when it comes to studies that compare large numbers of countries. In addition, the periodization used in presenting the data can vary considerably. Most of the multicountry studies present data decade by decade, thus obscuring the impact of major policy reform periods that seldom fit a decade-by-decade pattern. The growth accounting data referred to in this study of Southeast Asia are for the most part based on individual country studies that measured the sources of GDP or GDP per capita growth using data from individual countries' statistical offices and adjusted for known biases and gaps.

\section{Total factor productivity growth}

The first point to note about these studies is that most estimated that total factor productivity (TFP) played a small role in the growth of Southeast Asian economies. Singapore during its high catch-up growth years (1965-1990) is the exception. It had on average the highest TFP growth. In Southeast Asia, averaging a little less than $2 \%$ per year, although the rate fluctuated above and below that number (Bercuson, 1995). TFP growth in Malaysia and Thailand, in contrast, grew at around $1 \%$ a year over the entire post-1960 period covered in this study (Perkins et al., 2021). Indonesian TFP grew hardly at all from the period of recovery from the Sukarno years up to the present, although there may have been a period of positive TFP growth during the reform efforts of the 1980s and early 1990s (Van der Eng, 2006).

In Thailand, TFP growth was a bit faster than $1 \%$ up through 1996 , but not when one includes the financial crisis of 1997-1998 (Bosworth, 2005). Because this crisis in Thailand was a direct result of the preceding boom and due to the way that boom was financed and the macroeconomic policy failures of the Thai government, it makes sense to include that period in any estimate of the overall performance of the Thai economy. Much the same can be said about estimates for the Malaysian economy. For Malaysia and Indonesia, the impact of the 1997-1998 financial crisis was in part caused by external events, but most of all it resulted from local investors borrowing heavily in foreign currencies without hedging against foreign exchange rate risks. Governments followed macroeconomic policies to accommodate these practices until they ran out of foreign exchange reserves, the exchange rates fell and widespread bankruptcies ensued.

Vietnam's rapid TFP growth in the first half of the 1990s was due almost entirely to increases in efficiency made possible by dismantling the Soviet-style command system in favor of a market-based system. China experienced something similar in the 1980s when it dismantled the Soviet command system in favor of a market system. But for 15 years beginning in the mid-1990s, Vietnam experienced little TFP growth - well under $1 \%$ a year. Then, after 2010, TFP averaged over $2 \%$ per year until the COVID-19 pandemic in 2020 (Anh and Perkins, 2022). The Philippines from 1980 to 2000 had no growth in GDP per capita, and given that there was investment in those years, TFP growth on average must have been negative. Estimates of positive Philippine TFP growth, such as during the late 1980s, were productivity increases due not from sustained growth but because of recovery from a deep recession (in this case the ending of the Marcos-era predatory policies). Since the beginning of the $21^{\text {st }}$ century, however, the Philippines has experienced TFP growth a bit over $1 \%$ a year.

A $1 \%$ rate of TFP growth is better than the negative TFP growth that one has seen for long periods in much of Sub-Saharan Africa and in the 1980s Latin America. It is significantly less, however, than the higher TFP rates one saw during the high catch-up growth eras of China and Korea (Bosworth \& Collins, 2003). For the four best-performing economies in Southeast Asia, therefore, one needs to look elsewhere, at the rate of investment and capital formation, for what explains their relatively high GDP growth performance. The data on the investment rate (gross domestic capital formation/GDP) are presented in Figure 1. 


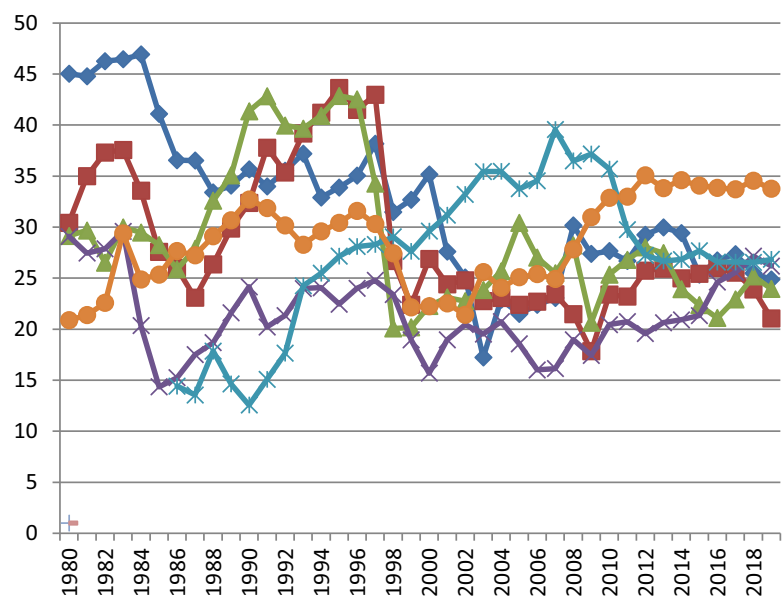

\section{Political influences in Southeast Asia}

$\sim$ Singapore

-Malaysia

Source(s): World Bank (2021)

\section{High investment rates}

The investment rates for Singapore, Malaysia and Thailand were at very high levels (35 to over $40 \%$ of GDP) throughout the 1980s and into the 1990s (Figure 1). The growth rates in Malaysia and Thailand then fell sharply after 1996 due to the financial crisis. For Singapore, this high rate went back to before the 1980s (there were nine years when the rate of investment was over $40 \%$ of GDP) and that was the period when GDP per capita growth annually averaged $6.2 \%$ a year. For Malaysia, the high investment rate of the 1980 s and 1990 s produced a very respectable increase in per capita GDP of $3.7 \%$ a year, but that rate was below the rate of the 1960s and 1970s when the investment rate was lower. It was only $0.5 \%$ higher than the rate of per capita GDP growth after 1999 when the investment rate was also much lower.

There is nothing mysterious about why the large increase in the rate of investment in Malaysia did not produce a similarly large increase in the growth rate of GDP. The 1980s, 1990s were the years when Prime Minister Mahathir poured large investments into a heavy industry program that was designed to produce a Malaysian automobile brand (Proton) along with the mechanical components and steel for its cars. Furthermore, this drive was designed to produce a political goal in the form of a heavy industry sector run by indigenous (Bumiputra) Malaysians, not Chinese Malaysians, and so it started with a group of stateowned enterprises. There were few Bumiputra with experience in manufacturing in the private sector, but through state-owned enterprises, the government could guarantee that Bumiputra would play a major role. The inefficiency of the resulting state-owned enterprises led to their privatization, albeit through private sales mainly to Bumiputra, most of whom had to be lent large sums from the government for this purpose. Those policies in turn made Malaysia vulnerable to the financial crisis that started soon after the crisis in Thailand. This Malaysian heavy industry effort never succeeded in producing automobiles and related industries that were internationally competitive.

The low return on investment experience in Thailand during the high-investment years was similar to that in Malaysia, but the policy failures that produced it were different. A large rise in the investment rate produced a high $4.7 \%$ GDP per capita growth rate, but it was only $0.1 \%$ higher than the rate of growth of the previous two decades when investment rates were lower. When the investment rate fell after 1999, the rate of growth in per capita GDP fell more 
FREP

1,1

than in Malaysia (from 4.7 to 3.4\%). The period of high Thai investment rates produced a real estate boom and bubble financed by heavy foreign borrowing. When the government ran out of foreign exchange, from its efforts to keep the exchange rate from falling, the rate then collapsed and the unhedged investors (indeed, most of the Thai investors) went bankrupt.

Vietnam experienced an investment boom during the first decade of the $21^{\text {st }}$ century, and that boom produced a per capita GDP growth rate of $5.6 \%$ - a high rate, but like Thailand and Malaysia, slightly below the per capita growth rate of the previous and following decades. That 2001-2010 decade was characterized by high levels of corruption and the continued reliance on state-owned enterprises for much of the Vietnamese economy. The decade also received a lower share of foreign direct investment than in either the previous or following decade.

Indonesian investment reached $35 \%$ of GDP during the second decade of the 21 st century, and that produced a $4.1 \%$ increase in per capita GDP during that decade. But a somewhat lower average investment rate during 1983-1997 produced a 4.7\% annual increase in GDP. The main difference between the two periods is that during the 1980s through the mid-1990s, Indonesian government policy was focused on expanding internationally competitive manufacturing and manufactured exports through deregulation measures. The share of manufacturing and manufactured exports rose steadily. Between 1983 and 1996, manufacturing rose from 13.4 to $25.6 \%$ of GDP and manufactured exports rose from 6.5 to $51.3 \%$ of total exports. After the financial crisis of 1997-1998, however, that effort came to an end and the share of manufacturing in GDP declined. By 2019, this had fallen to 19.7\%, and manufactured exports as a share of total exports declined to $46.3 \%$. Manufactured exports in most of the other Southeast Asian countries, in contrast, ranged from 75 to over $90 \%$ of exports (World Bank, 2021). Indonesia in the 21st century has relied more than the others on natural resource and service sector growth. Neither of these sectors was likely to produce the kinds of productivity growth that a country typically gets from the first phases of growth in manufacturing. Politically, it was easier for Indonesian governments to sustain adequate rates of GDP growth by relying on Indonesia's comparative natural resource wealth. It would have been politically more difficult to introduce the kinds of deregulation that would have been required to support increases in FDI in manufacturing.

Finally, among the six largest Southeast Asian economies, the Philippines had the lowest investment rate, with gross domestic capital formation as a percentage of GDP often falling below $20 \%$ and never rising above $25 \%$. The lower investment rate, combined with the predatory practices of the Marcos years leading to a long period of recovery from those practices, largely accounts for the slow Philippine growth rate. The rapid growth of the first two decades of the 21st century is partly explained by an investment rate that rose steadily from under $20 \%$ of GDP at the beginning of the century to $25 \%$ during the second decade. Given the populist nature of the Philippine government during this latter period, it remains to be seen whether this recent growth and investment rate can be sustained.

\section{Foreign direct investment}

There is a widespread view that rapid growth in much of Southeast Asia was made possible not only by a high rate of investment but particularly by a high rate of FID out of total investment. This compares, for example, with much of Northeast Asia (Japan, Korea and Taiwan), where FDI played a small role (China and Hong Kong being notable exceptions). This impression, however, is only partly true as the data in Figure 2 make clear.

FDI is a large part of Singapore's economic growth story, having been a large share of Singaporean gross investment since independence and accounting for a large majority of Singaporean investment in the 21st century. Singapore, like Hong Kong, pursued policies designed to make the country the hub for foreign companies in Southeast Asia. Its success 


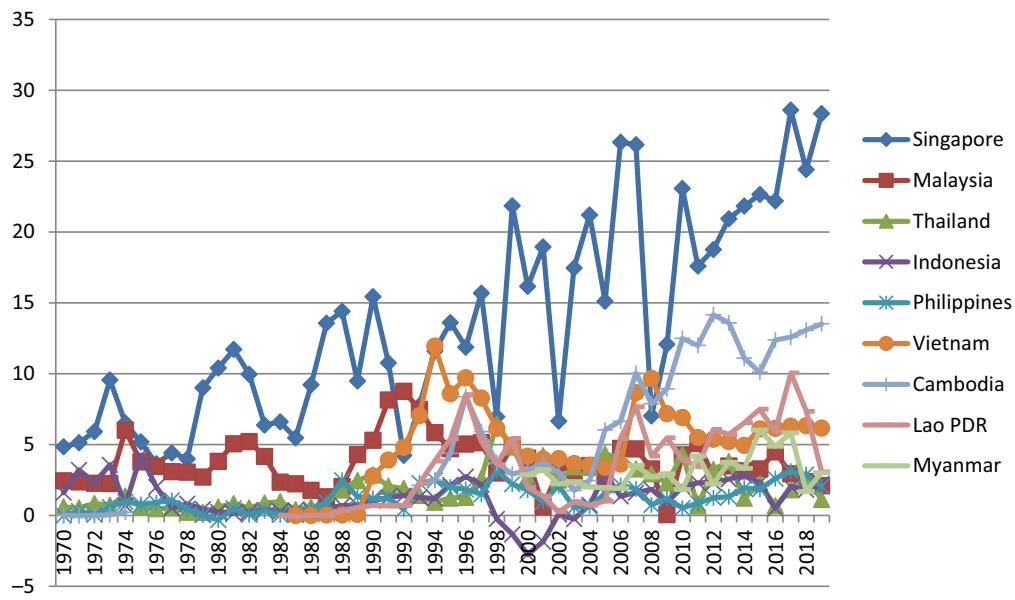

Source(s): World Bank (2021)

\section{Political influences in Southeast Asia}

Figure 2.

Southeast Asian net inflows of foreign direct investment (as $\%$ of GDP) $1970-2019$

in achieving that objective is clear. There are both successful domestically owned and state-owned companies in Singapore, but growth has been driven by a combination of foreign investment supported by a friendly regulatory environment and heavy government investments in arguably the best infrastructure in the region, if not the world.

The only other Southeast Asian nations where FDI has been a large share of investment and GDP - although nowhere near as large as Singapore - are Malaysia and Vietnam. In both countries, FDI-invested enterprises have accounted for most manufactured exports, and hence most of the foreign exchange earnings of the two economies. In neither country have domestic private firms been major competitors with the FDI firms. In Malaysia, domestic private firms have had to meet the Bumiputera ownership requirements imposed by the New Economic Policy instituted after the Malay riots of May 13, 1969. These requirements have been barriers to their ability to develop to a point at which they are internationally competitive and can export their products. FDI firms have typically been controlled or owned by large multinationals, and in contrast to domestic firms, they typically started as exporting firms and thus were exempt from Bumiputera ownership requirements. Vietnam has had a similar experience but for different reasons. To attract FDI firms, these were given special privileges early on. Domestic private firms of any size, in contrast, have faced many obstacles from a government that has strongly favored state-owned enterprises partly on ideological grounds and partly because these have kept large resources in the hands of the government and the Vietnamese Communist Party.

Laos, Cambodia and Myanmar have also attracted FDI, but only in the twenty-first century when some FDI firms, including Chinese firms, were looking to find alternative locations for labor-intensive manufacturing previously located in China. Investments in natural resources and real estate have also been common. The Myanmar military coup of February 2021 will probably limit FDI in that country, particularly if sanctions on trade are reimposed. FDI in Thailand, Indonesia and the Philippines has seldom been more than 1 to $2 \%$ of GDP. FDI share in manufactured exports, due largely to investments from Japan, has been much higher than the share in GDP. FDI in all of Southeast Asia has had a larger impact on growth than its share of GDP, largely through the demonstration effect of FDI firms' more advanced technologies and management practices. 
FREP

1,1

16
Corruption and the regulatory environment

Extreme predatory behavior by Southeast Asian governments had largely ended by the 21st century, with the exception of Myanmar's leaders. Some governments in the region have still continued to put up barriers to enterprise growth of a less extreme nature, however. The World Bank and Transparency International have been attempting to measure these barriers over the past two decades. Their estimates for several years are presented in Tables 3 and 4.

The first thing to note is that, with the exception of Singapore, Malaysia and Thailand, the other countries of Southeast Asia are difficult places to do business because of the regulatory environments imposed by their governments. With the exception only of Singapore, Southeast Asian nations are also very corrupt. The correlation between excessive

\begin{tabular}{lrr}
\hline Countries & 2020 & 2006 \\
\hline Singapore & 2 & 2 \\
Malaysia & 12 & 21 \\
Thailand & 21 & 20 \\
Brunei & 66 & $\mathrm{n} / \mathrm{a}$ \\
Vietnam & 70 & 99 \\
Indonesia & 73 & 115 \\
Philippines & 95 & 113 \\
Cambodia & 144 & 133 \\
Laos & 154 & 147 \\
Myanmar & 165 & $\mathrm{n} / \mathrm{a}$ \\
Korea & 5 & 27 \\
Japan & 29 & 10 \\
China & 31 & 91 \\
Hong Kong & 3 & 7 \\
India & 63 & 116 \\
Taiwan & 15 & 35 \\
Total & 190 & 155 \\
Source(s): World Bank (2005, 2020) & & \\
\hline
\end{tabular}

Table 3.

Ease of doing business ranking

\begin{tabular}{lrrr}
\hline & 2020 & 2007 & 1998 \\
\hline Singapore & 3 & 4 & 7 \\
Malaysia & 57 & 43 & 29 \\
Thailand & 104 & 84 & 61 \\
Philippines & 115 & 131 & 55 \\
Vietnam & 104 & 123 & 74 \\
Indonesia & 102 & 143 & 80 \\
Cambodia & 160 & 162 & $\mathrm{n} / \mathrm{a}$ \\
Laos & 134 & 168 & $\mathrm{n} / \mathrm{a}$ \\
Myanmar & $137 / \mathrm{n}$ & $\mathrm{n} / \mathrm{a}$ \\
Brunei & 35 & $\mathrm{n} / \mathrm{a}$ & 25 \\
Japan & 19 & 17 & 29 \\
Taiwan & 28 & 34 & 43 \\
South Korea & 33 & 43 & 52 \\
China & 78 & 72 & 66 \\
India & 86 & 72 & 86 \\
Total ranked & 183 & 181 & \\
Source(s): Transparency International & $(1998,2007,2020)$ & &
\end{tabular}

Table 4.

Transparency international corruption index rankings 
government regulation and corruption is not an accident. The more regulations a country has, the more opportunities there are for corrupt practices. Malaysia and Thailand are the only two countries in the region where it is comparatively easy to do business, and yet they are still ranked as quite or very corrupt. In the case of Malaysia, this may be because FDI firms are relatively free from corrupt government intervention, whereas some domestic investment is not. Many politicians in Malaysia use the Bumiputera laws, among others, to generate rents for themselves. The impact of this has been to slow growth below its full potential and to make the country dependent on FDI firms to provide manufactured exports. For Thailand, the high level of corruption probably accounts in part for the political instability of recent years. In both Malaysia and Thailand, however, the regulatory system overall provides a favorable climate for most businesses. For Malaysia at least, most of the corruption that is harmful to the economy appears to be in government-sponsored infrastructure development.

Myanmar, as already noted, is ranked as being very corrupt and the worst country in Southeast Asia - and one of the worst in the world - for doing business. It has been reported in the press that a major motivation for the February 2021 army coup was the desire on the part of the army to protect its corrupt rent-producing investments. Cambodia and Laos are also ranked among the worst countries for doing business and among the most corrupt. How then is it that, over the past two decades, their GDP per capita has grown rapidly? Both are among the smallest countries in Asia, with populations of 16 million and 7 million, respectively. A large share of their populations (75 and 65\%, respectively) are subsistence farmers, and literacy is low - only about a third of Cambodia's population has completed primary school and only $6 \%$ (in 2009) has completed secondary school (World Bank, 2021).

Growth in the two countries, as a result, has come mainly from FDI, not from domestic businesses. Many Chinese manufacturers of labor-intensive textiles, garments and shoes have moved their operations to Cambodia, presumably to take advantage of lower labor costs. FDI in Laos, in contrast, has gone into large hydroelectric projects that are built by Thailand and supply electricity mainly to their western neighbor. Laos receives rent from these activities, but it also must buy back from Thailand whatever electricity it uses. Laos also has a high-speed railway connecting it with China, built entirely by Chinese companies. Chinese companies do not have to contend with an equivalent of the US Foreign Corrupt Practices Act and can deal with Cambodian and Laotian regulatory and corruption barriers as simply a cost of doing business there. Vietnamese companies harvest large amounts of timber from Laotian forests, but it is not clear how much of this enters the official Laotian government statistics. An even larger illegal trade is in drugs, mainly from the "golden triangle" that includes both Laos and Myanmar. These drugs do not enter the GDP statistics for either country, but the services they purchase with drug money do. In Cambodia, there is also large and growing legal revenue from tourism that does involve domestic companies to some extent. The main positive aspects of the Cambodian and Laotian business environments are that their governments, unlike Myanmar, are reasonably stable and they abandoned Soviet-style planning in favor of market economies two decades ago. That said, most of the people of Laos are subsistence farmers and very little of the GDP growth ends up benefiting Laotians. Much the same can be said about Cambodia. A large share of the benefits of FDI goes to the foreigners who make the investment and to Cambodian politicians who oversee it. This is not likely to be an effective long-run growth strategy.

Vietnam, Indonesia and the Philippines fall between the comparatively favorable business environments of Singapore, Malaysia and Thailand and the extremely unfavorable ones of Myanmar, and to a lesser degree, Cambodia and Laos. Vietnam, Indonesia and the Philippines have also made significant progress in improving their regulatory environments and reducing corruption. There is no way in this short paper to analyze for these three countries the degree to which their business environments and corruption account for economic growth 
FREP 1,1

that is below their full potential. There is little doubt, however, that corruption and poor business environments are an important part of the story.

\section{Conclusion}

Government economic development policies are almost by definition driven by politics. The fastest-growing economies of Northeast Asia achieved high growth rates through political decisions that gave a near-absolute priority to measures that promoted growth. Political considerations that interfered with that priority were rejected. Rent-seeking and corruption, for example, existed in countries such as Korea, but rent-seeking interests were not allowed to influence industrial policy decisions, at least not during the first three decades of high growth. The same cannot be said about the nations of Southeast Asia, except for Singapore. The central point of this paper is that political-driven policies of two kinds explain much of the difference in the growth performance of Southeast Asian countries after the end of the Second World War. First were the extreme politics that led to war and revolution, together with the unusually predatory governments of Marcos in the Philippines, the military in Myanmar and the Khmer Rouge. There were also the governments driven by ideology - the imposition of Soviet-style centrally planned command economies in Vietnam, Cambodia and Laos. Then there were the nearly two decades of Sukarno posturing on the international stage rather than taking steps to improve the life of Indonesian people.

Once extreme politics were confined to the past, the second kind of politics continued to play a large role, particularly if one includes rent-seeking as a political act. The desire for rents had much to do with why the regulatory environment has been so unfavorable in many Southeast Asian countries, although government distrust of private business practices was also involved. Decisions to support or oppose FDI have also been, first and foremost, political, particularly where domestic ownership is by minority ethnic Chinese. In Malaysia, it has been a way to grow exports while still imposing stiff ownership-sharing requirements on ChineseMalaysian businesses. In Vietnam, it has partly been a decision to strengthen relations with high-income market economies but not so much China. In Cambodia and Laos, relations with China have largely dictated who the principal foreign investors are. Natural resource incomes have made it possible for some politicians, such as the Myanmar army, to close themselves off from the world.

Singapore under Lee Kuan Yew and the People's Action Party, in contrast, understood that to survive as a politically independent country - one surrounded by less than friendly neighbors and a local population many of whom had supported the Communist insurgency it had to be an economic success that benefited most of its citizens. Singapore had that in common with South Korea and Taiwan - two economies that knew their survival depended on shared economic success. These economies are among the few in the developing world that have reached their full catch-up economic growth potential by giving growth-oriented policies an absolute priority.

Politics, of course, is not the whole story of Southeast Asia's economic growth. There have been fundamental differences in the level of education of populations due in part to different colonial experiences and also differences between Confucian and non-Confucian cultures. Tertiary-level education throughout the region, in particular, has been weak, with the exception of Singapore. Investment rates, nevertheless, have been high enough to sustain fairly high growth rates, despite the inefficiencies resulting from high levels of corruption and politically motivated regulation.

The emphasis in this paper has been on how politics have distorted economic decisions from what a technocratic high economic growth strategy would have dictated. On a positive note, however, once the countries in the region managed to get beyond wars and revolutions, it was the politicians who decided that economic growth was important and created policy 
contexts that were sufficient to support high levels of investment. The difference between most of Southeast Asia and Northeast Asia is that commitment to high investment and growth has been less than absolute. It may seem obvious that governments in developing countries would give high priority to policies that promote economic growth, but the world is full of examples of governments that have given priority to other goals that have stifled growth. Political leaders, who have long overstayed their welcome but are determined to hold onto power, even if the methods used stifle economic growth, are found in many places. In Southeast Asia, however, most political leaders have supported economic growth policies just not with the single-minded focus that occurred in Northeast Asian countries during their high catch-up growth decades.

It is also true that some of the policies that at first glance appear to have slowed growth may have helped create the sustained political stability that has allowed growth to continue. Malaysia's NEP, introduced after the May 1969 riots, is a case in point. For all of the negative effects this policy sometimes had on domestic investment and growth, it also gave the majority Malay population a stake in the country's progress. Indonesian industrial policies under the country's 21st century democracy may be inferior to the technocratic industrial policies of the 1980s and early 1990s. The government during this period, however, went on to distort those technocratic policies for personal gain, which led to the economic and political collapse of the regime. Few in the country would trade the democracy that followed for better economic policies; democracy also appears to have created a more stable environment for long-term investment.

Indonesia aside, this paper has not tried to answer the question of whether economic growth depends ultimately on political systems that allow for full citizen participation in governance - systems that are full democracies in some sense. In Southeast Asia, the only country that can be considered a full democracy is Indonesia, and only for the two most recent decades. The Philippines also comes close, in that contested elections are regularly held and governments change from one party or part of the electorate to another. Malaysia and Singapore also have contested elections where the votes are counted honestly, but the playing field is heavily biased toward the existing ruling party, and only once in Malaysia and never in Singapore has the ruling party lost an election. Thailand and Myanmar have elections, but it is still the military more often than not that decides who will govern. Vietnam, Cambodia, Laos and Brunei are unapologetically authoritarian. In Southeast Asia, there is no correlation between economic growth performance and the degree of citizen participation in governance.

Finally, this paper has argued that sustained economic growth in Southeast Asia occurred when there were long periods of political stability that created a stable environment for investment. The paper has not argued that economic growth justifies the ways that political stability has been achieved. As the Indonesian example illustrates, somewhat less growth but more democracy can sometimes mean a higher level of human welfare. Most of the political leaders of Southeast Asia, however, have not accepted that view.

\section{Notes}

1. The economy of South Vietnam may have achieved increases in GDP in the 1955-1972 period, but it was growth generated by massive military and aid expenditures in the country by the United States connected to the war effort.

2. There are estimates of when the GDP growth slowdown occurred for all countries that achieved high income status. For most, this occurred when they reached between $\$ 10,000$ and $\$ 16,000$ per capita GDP (Purchasing Power Parity year 2000 prices)

3. A slowdown due to poor policies can occur at any time, but the kind of slowdown noted here refers to a slowdown that occurs because the country has reached a per capita income where catch-up growth (e.g. growth by basically following the path laid down by leading high-income economies). 


\section{FREP 1,1}

\section{Reference}

Alesina, A., Özler, S., Roubini, N., \& Swagel, P. (1996). Political instability and economic growth. Journal of Economic Growth, 1(2), 189-211.

Anh, V.T.T., \& Perkins, D.H. (2022). Explaining vietnam's economic growth experience. unpublished book chapter, in Ljunggren, B. and Perkins, D.H. (Eds), Vietnam: Navigating a Rapidly Changing Economy, Society, and Political Order.

Bercuson, M.K. (1995). Singapore: a case study in rapid development, IMF Occasional Papers 1995/ 018, International Monetary Fund, Washington, DC.

Bosworth, B. (2005). Economic Growth in Thailand: The Macroeconomic Context a World Bank Project on the Investment Climate, Firm Competitiveness, and Growth in Thailand, Washington, DC.

Bosworth, B., \& Collins, S.M. (2003). The empirics of growth: An update. Brookings Papers on Economic Activity, 2003(2), 113-206.

Perkins, D.H., Rasiah, R., \& Woo, W.T. (2021). Explaining Malaysia's past economic growth. unpublished book chapter, in, Rasiah, R., Saleh, K. and Check, C.K. (Eds), Malaysia's Leap into the Future: Building Blocks, Springer, New York.

Robinson, J.A., \& Acemoglu, D. (2012). Why Nations Fail: The Origins of Power, Prosperity and Poverty Profile, London.

Shah, N. (2017). Charting the Economy: Early 20th Century Malaya and Contemporary Malaysian Contrasts, Oxford University Press, Oxford.

Transparency International (1998, 2007, 2012, 2020). Corruption Perceptions Index, Berlin.

Van der Eng, P. (2006). Accounting for Indonesia's economic growth: Recent past and near future. Seminar on World Economic Performance: Past, Present and Future-Long Term Performance and Prospects of Australia and Major Asian Economies, on the Occasion of Angus Maddison's 80th Birthday, University of Queensland, Brisbane, 5-6.

World Bank (2005, 2020). Ease of Doing Business Ranking, Washington, DC.

World Bank (2021). World Development Indicators, Washington, DC.

\section{Corresponding author}

Dwight Perkins can be contacted at: dwight_perkins@harvard.edu

For instructions on how to order reprints of this article, please visit our website:

www.emeraldgrouppublishing.com/licensing/reprints.htm

Or contact us for further details: permissions@emeraldinsight.com 